\title{
Correction to: Primary vitrectomy with short-term silicone oil tamponade for uncomplicated rhegmatogenous retinal detachment
}

\author{
Murat Karacorlu • Mumin Hocaoglu • Isil Sayman Muslubas • M. Giray Ersoz • \\ Serra Arf • Omer Uysal
}

Published online: 1 August 2018

(C) Springer Nature B.V. 2018

\section{Correction to: Int Ophthalmol \\ https://doi.org/10.1007/s10792-017-0787-9}

Dear editor and readers, this letter is written to make you aware that the original version of this article unfortunately contained a mistake.

There was an error in the results section of the abstract. "The mean duration of SO tamponade in phakic eyes was $8.5 \pm 1.9$ and in pseudophakic eyes was $8.3 \pm 1.9$ months $(P=0.39)$ ". The word "months" in the above sentence has been used incorrectly. The correct word is "weeks", as stated in discussion section and tables. It should read as "The mean duration of SO tamponade in phakic eyes was $8.5 \pm 1.9$ and in pseudophakic eyes was $8.3 \pm 1.9$ weeks $(P=0.39)$ ".

This may have led to some confusion for many of the readers, for which we apologize.

The original article can be found online at https:// doi.org/10.1007/s10792-017-0787-9.

M. Karacorlu $(\bowtie) \cdot$ M. Hocaoglu .

I. Sayman Muslubas · M. G. Ersoz · S. Arf Istanbul Retina Institute, Hakkı Yeten Cad. Unimed Center No: 19/7, Fulya - Şişli, 34349 Istanbul, Turkey

e-mail: mkaracorlu@gmail.com

O. Uysal

Department of Biostatistics, School of Medicine,

Bezmialem Vakif University, Istanbul, Turkey 